\title{
THE DIARY OF JULIA COLT BUTLER
}

\author{
$1889-1890$
}

\section{$B Y$ MELISSA A. WENSEL}

Ms. Wensel is a master's candidate in the English Department, Rutgers University

I $\mathrm{N}$ attempting to piece together the feminine heritage of America, modern scholars quickly discover that the public record is not particularly useful. In the last century, when the majority of women lived in an almost entirely private sphere, no effort was made to preserve their stories for posterity. Consequently, private writings such as letters and, in particular, diaries and journals have become the primary sources for insight into the experiences of women. Were it not for the diaries kept by many nineteenth-century women, such as the one written by Julia Colt Butler, the records of their lives would be entirely obscured. Julia's diary, kept from June 28, I 889 to December 8 , I 890 , provides a brief but valuable glance into the life of a young upper-class woman. ${ }^{\mathrm{I}}$ The diary reveals its writer as a spirited young woman with little opportunity for excitement within the constraints of her protected environment. Yet, Julia apparently did not protest her lot, but rather accepted the values of bourgeois American society in the passively uncritical manner which characterizes the tone of her journal. She belonged to an entire class of idle women whose social function appears to have been that of the consumer — of goods, of time, and of culture.

Julia Colt Butler was born June 29, I 872 , in Paterson, New Jersey. At that time Paterson was a booming industrial center, commonly known as "Silk City" for its production of fine textiles." On her paternal side Julia was descended from one of the most prominent and wealthy families in Paterson, the Colts. Julia's greatgreat grandfather, Peter Colt, and his sons Roswell and John, were early founders of industry in Paterson and were cousins of Samuel

' Julia Colt Butler's diary can be found in the-Francis E. Butler Papers held in the Special Collections of Rutgers University. In addition to her diary are also a scrapbook which she kept from 1902 to 1903 and a family photo album with several photographs of Julia.

${ }^{2}$ For more information on Paterson and the Colt family's role in its industrial development, see William Nelson and Charles A. Shriner, Paterson and Its Environs, Vol. I (New York: Lewis Historical Publishing Company, 1920), pp. 333-337. 


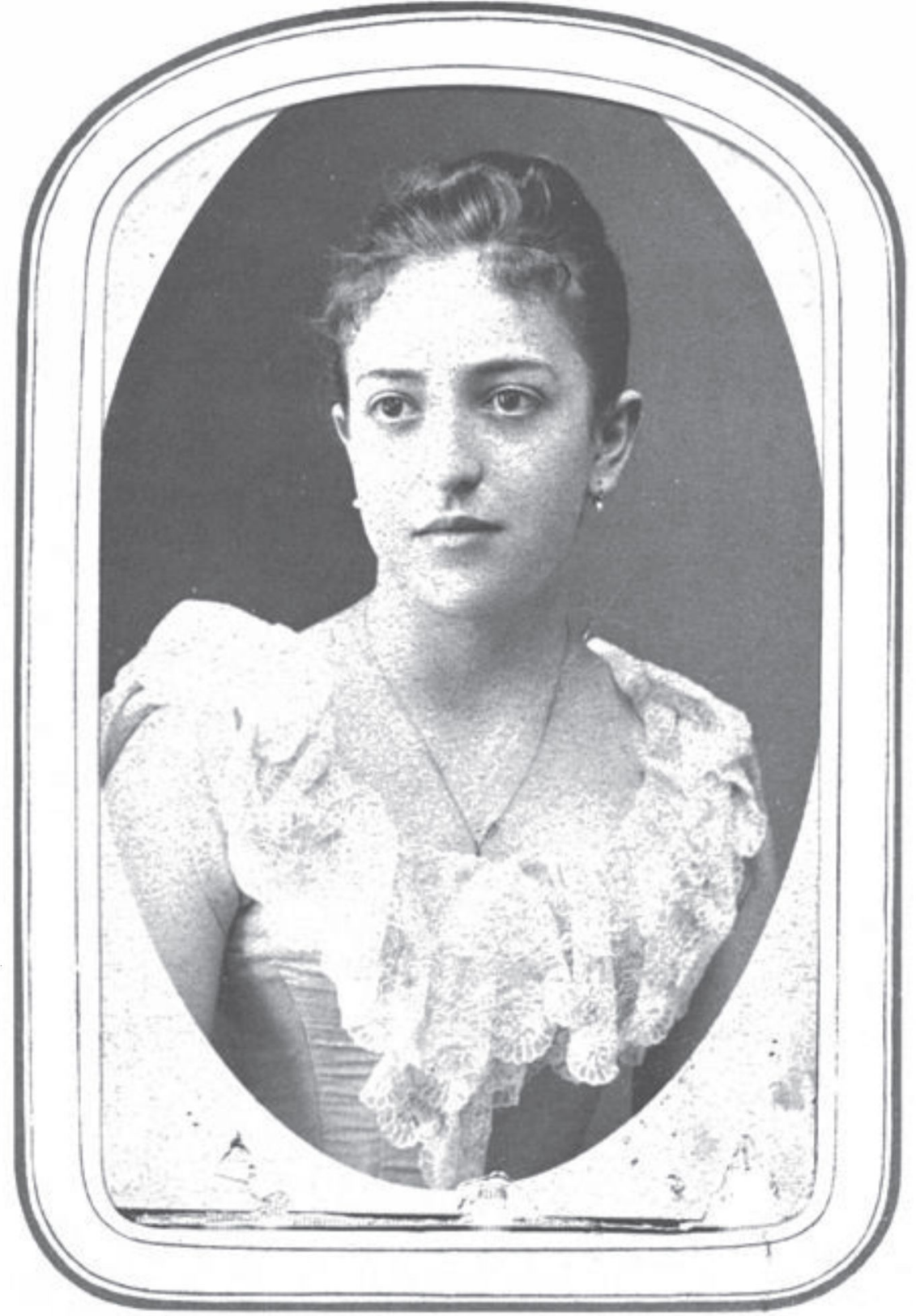

JULIA COLT BUTLER (Special Collections and Archives, Alexander Library) 
Colt, inventor of the "Colt 45 " pistol. 3 In I 84 I the two clans of Colt and Butler joined in the marriage of Julia Marian Colt and Henry V. Butler, Julia's grandparents. The I 859 Paterson City Directory shows that Julia's grandfather owned and operated the Ivanhoe Mill, a paper mill. ${ }^{4}$ The I 880 U.S. Census lists her father's occupation as "Paper Manufg," so it seems he stepped into the family business. The I 880 Census reveals that Julia was one of three children, having a sister, Mary, two years older, and a brother, Henry Jr., two years younger. Also residing in their home at 2 I 4 Broadway were a French governess, three female servants, and a coachman. In her diary and a scrapbook of social memorabilia Julia mentions the names of Barbour, DeGrasse, Ryle, Pennington, and Woodruff, all relations or friends who were also extremely prominent manufacturing families in Paterson. On the basis of this evidence it becomes clear that Julia's social milieu was an elite circle thoroughly steeped in early American capitalism.

As an unmarried seventeen-year-old, Julia's life was one of easy leisure. Her days and evenings were filled with social activities, school while in Paterson, and such quiet pursuits as reading or letter-writing. Her regular diary entries describe her family summer vacation in I 889 visiting relatives in New England, daily life in Paterson, and most interesting, a trip abroad to France in I 890. During the summer holiday she and her cousins played charades, tennis, and numerous card games. On hot summer days they enjoyed "lawn pool and lemonade," took long drives in the country, saw band concerts, and went to local plays and dances. Julia was a high-spirited girl who loved practical jokes and drives in the rain. Social life in Paterson appears to have been somewhat quieter. School seems not to have been particularly interesting, since Julia says nothing more about it than: "Went to school." One suspects that she was not an especially diligent or gifted student; she writes in Paris: "Had a horrid french lesson and cried some." Her French continued to vex her, but she enjoyed her less scholarly morning music lessons. At home she was far more concerned with the social

${ }^{3}$ For more on the Colt family, see The Colt Family in Paterson (Paterson, NJ: The Jerseymen of Paterson Catholic Regional High School, I978).

4 William H. Boyd, ed., I 859 Paterson City Directory (New York: D. Appleton \& Co., I 859 ), p. 23. 
excitement of Princeton-Yale football games than with her own school.

The modern reader may well ask what motivated such a lighthearted girl to keep a diary. In his book The Bourgeois Experience, Peter Gay calls the nineteenth century "the golden age" of the diary. ${ }^{5}$ He writes:

... in an individualistic, introspective, and reticent century like the nineteenth, the diary and the journal proved particularly congenial and became almost obligatory companions to a class endowed with a modicum of leisure. ${ }^{6}$

Gay claims that diaries were often used as private confessors, surrogate companions, and even as a kind of therapy. However, Julia's diary is not an intimate companion to whom she could entrust her dearest secrets. It is instead a fairly careful chronological report of daily events. Julia did, however, have more than just a "modicum of leisure." Certainly a diary gave her something to fill her idle hours and an opportunity to relive interesting episodes. During periods in which Julia had something engrossing to do, the length of her entries dwindles. Just prior to her departure for France there is a conspicuous gap of several blank pages, representing a time in which she was too busy to write. Peter Gay comments: "Activity and diary-writing were normally adversaries." 7 That so many young women of Julia's social station also kept diaries is not only "symptomatic for bourgeois styles of thinking," as Gay maintains, but symptomatic for the social realities of woman's place in bourgeois culture. In many respects these young ladies had become "nonfunctional" members of their society for whom activities had to be created.

Julia's life at this time was a very private world, lived mainly among female relatives and friends. The public world figures into her diary only in terms of social events. The larger worlds of serious literature, religion, politics, and business don't seem to have touched her personally. For example, one would never guess from her journal that Henry V. Butler was a wealthy industrialist, because Julia knew him only in his private capacity as "Papa." It would be accurate to say that she inhabited the "domestic sphere," fairly

s Peter Gay, The Bourgeois Experience, Victoria to Freud (Oxford: Oxford University Press, I 984 ), p. 446 .

${ }^{6}$ Ibid., p. 447.

7 Ibid., p. $45 \mathrm{I}$. 
oblivious to the public sphere of men that gets recorded in history books. However, it would be inaccurate to assume that her life reflects the cultural characteristics associated with nineteenth-century "women's culture," as it has been described by such feminist scholars as Carroll Smith-Rosenberg and Nina Baym. In "The Female World of Love and Ritual" Carroll Smith-Rosenberg writes:

. . . most nineteenth-century Americans assumed the existence of a world composed of distinctly male and female spheres, spheres determined by the immutable laws of God and nature. The unpublished letters and diaries of Americans during this same period concur, detailing the existence of sexually segregated worlds inhabited by human beings with different values, expectations, and personalities. ${ }^{8}$

The values that help define "women's culture" are close female bonding and an ethos of domesticity and pious self-sacrifice. Julia may have lived in the domestic sphere, but the ideological aspects of "women's culture" seem to have played no real role in her life. There is no clear evidence of the close female bonding that SmithRosenberg describes, for example, although one can recognize the semblance of "an inner core of kin" comprised of "sisters, first cousins, aunts and nieces." 9 Nor were piety and self-sacrifice central values for Julia. Twice she briefly mentions visiting sick relatives, and once she and her mother go on a social/philanthropic mission to see "Fanny Hill a poor lame girl at Hospital." There appears to have been no overt moral or religious motivation for these actions. Religion played a more or less social role in her life. Although Sundays demanded an obligatory display of religiosity, the Sabbath was turned into a pleasant day of church-going, visiting, and hymnsinging in the evening. She makes absolutely no religious reflections. Christmas is a secular (and materialistic) event; she writes: "Christmas day, received all the presents I wanted, besides money." 10 Sunday on the steamer to Europe she reads in "Daily Strength for Daily Needs," and once in Paris she remarks that she read in her

\footnotetext{
${ }^{8}$ Carroll Smith-Rosenberg, "The Female World of Love and Ritual: Relations Between Women in Nineteenth-Century America," in A Heritage of Her Own, Toward a New Social History of American Women, ed. Nancy F. Cott and Elizabeth H. Pleck (New York: Simon and Schuster, 1979), p. 318. This article was reprinted from Signs I, no. I (Autumn I 975):9.

9 Ibid., p. 3 I 9.

10 Julia Colt Butler, Diary, Dec. 25, i 889.
} 
Bible because it was too rainy to go to church! While in Paris she went to “. . . the American Church, 'Holy 'Trinity' although it was Episcopalian, it seemed good to go to an American Church ..." The church is a comforting reminder of home, a cultural symbol, not a religious symbol. She is not critical of foreign religious practices, however. She attends both Roman Catholic and Russian Orthodox services and reports of them in an interested but unbiased way. Like the great cathedrals, foreign religions seem to have been part of the cultural "sights" of Europe for Julia.

If one subversive element in "women's culture" is its implicit critique of male materialism, then this is another component apparently missing from Julia's experience. As an enthusiastic consumer, she was an active agent in the male world of commerce, even if she was ignorant of its inner workings. So, although Julia occupied a private "domestic sphere," it was not one that could be characterized as a "self-created women's culture" with its own set of values, but rather as a separate sphere for women which functioned within the dominant culture without questioning its presuppositions.

There are many possible reasons why Julia's experience must be defined largely in opposition to the concept of "women's culture." First, it is clear that in any generalized view of a culture, there are always exceptions. Every woman need not subscribe to the cultural norm. Second, Julia's diary was written so late in the century that the terms "women's culture" and the "cult of domesticity" may have begun to lose some of their relevance. Third, and probably most important, the concept of "women's culture" refers more specifically to the experience and sphere of middle-class American women. Julia belonged to the wealthy elite of Paterson. Her life and writing were very unlikely to produce a critique of the very milieu that formed them. In such a social setting it is not surprising that her outlook was very secular and uncritical of the materialistic world. The difference is not so much one of time or individual variation, but one of class.

Paradoxically, Julia seems to have been fully integrated into a society that marginalized her as a woman. Her role as a female in the dominant culture was a fairly passive one. The tone of her diary reflects this passivity in its reserve and unself-consciousness. Julia does not contemplate the state of her mind, soul, or life. She makes 
no general statements of satisfaction or dissatisfaction with her life. Her perceptions are very local and immediate, so that the reader must piece together a broader picture of Julia's life and personality. Her personal comments are usually short, expressing only general feelings of pleasure or displeasure. A typical entry states: ". . . Miss Reed came to dinner in the eve Mr. Spiers came in. We tried puzzles \& had tea $\&$ cake and so passed a very pleasant evening." "I Her feelings tend to be very nonjudgmental and unopinionated. The strongest negative remark she makes of a person is of a New York dentist whom she calls a "wretched beast" for hurting her tooth. Otherwise she tries to qualify or moderate such opinions. Her positive judgments are also limited. She makes no comments on personal character or virtue, although she does obviously value entertaining personalities, such as her cousin Charlie. This may indicate immaturity, but it also suggests a certain reticence or discomfort in expressing strong opinions.

Likewise, Julia doesn't comment on the world as a whole or even her little piece of it. She seems to absorb many of her attitudes and judgments from others; this is obvious in her reports of sight-seeing in Paris. She is the classic American tourist, dictating pedantically the details and language from descriptions of famous monuments she has either heard or read. For example, she describes the painter Wiertz: "He more nearly approached Rubens in strength and majesty of conception and in perfection of colouring than any other Modern Artist has done." 12 She has a penchant for passively adopting judgments, although she is perfectly capable of forming her own: ". . . some parts of the inside of the church I liked better than the Cathedral, but the stain glass windows were not as handsome . . ." 33 She declines for the most part to pass moral or aesthetic judgment, conforming her views to those of masculine "experts." The following excerpt illustrates well her uncertainty in trusting entirely to her own judgment, alternating between the voice of "authority" and her own authentic perceptions:

We left the tram at Rue Bonapart . . \& \& walked to the church; but I have not a very good idea of it, and it was so full of people, it was impossible to see much of it, except that it is a very large \& important old church. It has the finest organ in Paris . . . back of
"Ibid., Sept. 25, I 890.
${ }^{12}$ Ibid., Sept. 5, 1890.
13 Idem. 
the large central altar is an immense choir made up of the Seminaristes . . . standing at one end, on either side you look down through at least eight arches, the effect of this was peculiarly beautiful-as we saw it was so late when we entered that all the more brilliant candles and gas lights had been extinguished and the broad aisles $\&$ sobre arches were only lighted by the lamps which burned dimly in the various chapels . . . ${ }^{14}$

This tendency to distrust her own experience says something not only about her submission to male voices of authority, but also something about the entire purpose of Julia's European sojourn. Hers was obviously the classic trip abroad, considered almost essential to "finish" an upper-class girl with a nice French accent and a gloss of "culture." In nineteenth-century bourgeois America, culture was not something that a young woman created, but something she acquired. Surely the acquisitive desire was a trademark of the American bourgeoisie, but women seem to have been marked out especially as consumers. In writing of "literary domesticity" in nineteenth-century America, Mary Kelley links this cultural consumerism to the strictly private role assigned women in their society:

With a presumed destiny that was private, not public, and a role that called for the support of others, women could become receptors of culture. ${ }^{\text {I5 }}$

The public sphere of culture (art, literature, politics, etc.) was a male domain in which women were to act as passive conservative agents. Julia's trips to famous landmarks and museums were, in a sense, cultural shopping sprees. She was simultaneously a woman consuming male culture and an American appropriating European culture.

Julia's consumerism manifests itself in even more obvious ways in her journal. While in Paris she fastidiously notes the purchase of gloves, writing paper and other trifles and makes curiously minute observations on the cost of tram and theatre tickets, even though such expenses were surely unimportant to a girl in her social position. She obviously thoroughly enjoys the activities of shopping and buying. She seems to prefigure the modern middle-class bargain-hunter. In her book The Feminization of American Culture,

14 Ibid., Nov. I, I 890.

is Mary Kelley, Private Woman, Public Stage (Oxford: Oxford University Press, 1984), p. 168 . 
historian Ann Douglas describes the disestablishment of women from their creative functions in the economic processes in nineteenth-century America:

In the newly commercialized and urbanized America of the middle of the nineteenth century, the woman consumer . . . is more important ... than the woman producer. ${ }^{16}$

Any real work is conspicuously absent from descriptions of Julia's days. She does mention doing embroidery or fancy work, but it figures in as no major occupation. Julia was, however, an active reader and prolific letter-writer. She writes often of her letterwriting, but says nothing of its content. Although she writes primarily to her mother and father while in Paris, she never really expresses emotions of missing them. This leads one to suspect that her letter-writing was largely an habitual pastime. Reading appears to have been something on a par with her letter-writing, something to occupy her time. She rarely mentions so much as a book title. A typical entry notes: ". . . and I read a book the rest of the afternoon." Julia was what Ann Douglas would probably call a "consumer of literature." 17 It is not surprising that with the rise of the affluent and middle-class woman came the rise of popular literature and domestic journalism.

Julia's European experience was obviously intended primarily as a polishing exercise, perhaps to make her more "marketable" as the bride of a young manufacturer. Julia had a fairly regular schedule in Paris: breakfast at 8:30, French lessons from I I to I 2 o'clock, dinner at noon, and tea at 5:00. One journal entry states: "Chocolate and french as usual, which occupy most of my mornings." ${ }_{18}$ The rest of the time was reserved for excursions to museums, parks, historic "sights," and the theatre and opera. ${ }^{19}$ However, the experience abroad also appears to have been a time when Julia was able to develop a new sense of independence. It was probably her first extended period away from parental supervision in a large metropolis, although the group of girls was closely chaperoned. A

\footnotetext{
${ }^{16}$ Ann Douglas, The Feminization of American Culture (New York: Avon Books, I 977), p. 77

${ }_{17}$ Ibid., p. 72 .

${ }_{18}^{8}$ Julia Colt Butler, Sept. I3, 1890.

19 Julia's later scrapbook (1902-03) is composed mainly of programs from plays, concerts, and operas, which indicates that this became a vital part of her adult social life.
} 
series of entries reveal Julia's growing pride in her new-found independence:

Emma \& I went out to mail a letter and of course I wanted it to be my first errand in Paris alone...

Came up to I 2 Ave. Victor Hugo by myself on tram top.

Emma and I came back alone for the first time since we were in Paris on a tram alone. I felt quite old. ${ }^{20}$

This may seem to the modern reader sweet and amusing, but it was obviously very important to Julia, who lived what must have been an extremely sheltered life.

Julia's experience aboard the ship to Europe provides one of the most amusing and interesting episodes in the journal. She writes of her feelings as the ship leaves the harbor, separating her from home and family: ". . . it was pretty hard to keep up my spirits." The parting is difficult, but she soon enters into the spirit of the adventure. She is, after all, not travelling alone. Her group of eight includes four young ladies, three older married women, and Willie, most likely a younger child of one of the married ladies.

In spite of the presence of chaperones, Julia experiences a new freedom on board ship. She strikes up a friendly flirtation with the ship's fourth officer and mischievously pesters the captain; she writes: “. . . yesterday I went into the Captain's cabin and he took me by the collar and put me out, much to my disgust." ${ }_{22}$ She literally revels in a day of rough seas:

I awoke early and was almost tossed out of bed; finding it pretty rough, but that was nothing, as I am now what you might call a "tuff." O! this tossing from one side to the other, so that the water comes away up above your port hole is elegant. After breakfast Willie and I stood away out on the bow and was nicely soaked by a big wave. Not many ladies on deck who were not sick. . . . Three ladies tumbled out of their chairs on deck, but were not hurt; have learnt how to walk when the ship is nearly perpendicular-had a game of six handed euchre in the eve-the dishes were cased in on the table but notwithstanding, the eatables dumped out of them and glasses upset, oh! it is real fun to be able to enjoy it so much. ${ }^{23}$

${ }^{20}$ Julia Colt Butler, Sept. 16, 23, I8, 1890.

${ }_{21}$ Ibid., Aug. 20, 1890.

${ }_{22}^{2}$ Ibid., Aug. 27, 1890.

${ }^{23}$ Ibid., Aug. 26, I 890. 
She obviously prides herself on being stronger than the other women. In fact, she strikes a characteristically romantic male pose, exulting in the wind and the waves out on the ship's bow. She was surely not entirely unfamiliar with such images, living in a post-Melville age. There are indications throughout the diary that Julia is a spirited creature, ready for any adventure, but the sphere of her life is restricted. Nothing really exciting happens in her world in Paterson, so she delights in small pranks. A ship, however, no matter how closely it may approximate a mobile "mini-culture," complete with elegant dining rooms and shuffleboard, is somehow outside of culture. Life is suddenly makeshift, if comfortable, living out of "steamer bags." The sea and ships represent a kind of cultural "wild zone" in which Julia is able to put on her "steamer cap" and simultaneously take off some cultural restraints. ${ }^{24}$ Once on dry land again, however, Julia is far more subdued.

The portrait of Julia Colt Butler that emerges from her diary is of a cheerful, lively young woman whose culture failed to provide her with meaningful outlets for her energies. Marginalized into an almost entirely private sphere of existence, she became a passive consumer of goods and culture. Yet, even in such a situation there is room for revolt. Florence Nightingale, strangled by the same kind of unproductive existence, eventually broke free to do her work. ${ }^{25}$ Julia, however, seems to have been basically content with her life as an idle socialite. She makes no complaint in her journal, yet one wonders what her life could have been like had she been offered a larger part of the world in which to move. Whether Julia asked herself similar questions later in life will probably remain unknown, since a more complete record of her experience has not been preserved by history.

${ }^{24}$ On the term "wild zone" and its relationship to separate male and female spheres, see Elaine Showalter, "Feminist Criticism in the Wilderness," Critical Inquiry 8 (Winter 198I) 2:179-205.

${ }_{25}$ On Nightingale, see Florence Nightingale, Cassandra, ed. Myra Stark (New York: The Feminist Press, 1979). 